Note

\title{
Depression of Phagocytic Activity of Human Polymorphonuclear Leukocytes by Methyl Linoleate Hydroperoxides
}

\author{
Motoko OARADA, Nobuyuki Kurita, Makoto MiYaJi, \\ and Kiyoshi TERAO \\ Research Center for Pathogenic Fungi and Microbial Toxicoses, \\ Chiba University, Inohana, Chiba 280, Japan
}

(Received June 7, 1991)

\begin{abstract}
Summary Methyl linoleate hydroperoxides (MLHPO), a model for lipid hydroperoxides, decreased fungicidal activity of human polymorphonuclear leukocytes (PMN) for fungi of Candida albicans. When PMN was cultured with MLHPO, phagocytosis to fungi was depressed. Degree of the depression was dependent on the concentration of MLHPO and the treatment time with MLHPO. These findings indicate that phagocytic activity of human PMN can be depressed by lipid hydroperoxides.
\end{abstract}

Key Words lipid peroxides, polymorphonuclear leukocytes, phagocytosis

Several studies have been reported on the nutritive problems associated with dietary lipid hydroperoxides, and it was proved that lipid hydroperoxides were absorbed and incorporated into several organs of animals after an oral administration (1). Furthermore, the formation of lipid hydroperoxides in animal tissues has been reported (2), and the presence of lipid hydroperoxides in human plasma has been proved using a chemiluminescence detection-high performance liquid chromatography system (3). To know the influence of these lipid hydroperoxides on animals, methyl linoleate hydroperoxides (MLHPO) or autoxidized soybean oil have been orally administered to mice, and it has been found that lipid hydroperoxides cause significant effect to the maturation of thymocytes $(4,5)$. Other kinds of immunocompetent cells such as polymorphonuclear leukocytes (PMN) generate unstable reduction products of oxygen during phagocytosis. It has been observed that phagocytosis is attenuated by autoxidative damage to the cell membrane by these endogenously derived oxygen by-products (6). Therefore, it is thought that PMN would be affected by dietary lipid hydroperoxides and/or lipid hydroperoxides generated in tissues. In this study, we have shown that phagocytic activity of human PMN is depressed by lipid hydroperoxides.

MLHPO was prepared as described previously (7). The purified MLHPO has a peroxide value (PV) of $6,086 \mathrm{meq} / \mathrm{kg}$. To isolate human $\mathrm{PMN}, 20 \mathrm{ml}$ of 
heparinized blood (10 U of heparin/ml) from healthy donors was mixed with $4 \mathrm{ml}$ of $6 \%$ Dextran T 250 (Pharmacia, Sweden) and allowed to stand at $37^{\circ} \mathrm{C}$ for 45 min. Then $12 \mathrm{ml}$ of the buffy coat was collected and diluted with $12 \mathrm{ml}$ of RPMI1640 (GIBCO Laboratories, NY); $8 \mathrm{ml}$ of diluted buffy coat was then layered over $3 \mathrm{ml}$ of Histopaque $(d=1.077$, Sigma Chemical Company, St.Louis) in $15 \mathrm{ml}$ conical plastic centrifuge tubes. Centrifugation was done at $400 \times g$ for $40 \mathrm{~min}$. Pellets were washed once with RPMI-1640 and treated with Tris-buffered $0.84 \%$ ammonium chloride ( $\mathrm{pH}$ 7.2) to lyse contaminating red blood cells. Treated cells were washed with RPMI-1640 and suspended in complete tissue culture medium [CTCM; 80\% RPMI-1640, penicillin (100 U/ml), streptomycin $(100 \mu \mathrm{g} / \mathrm{ml}), 10 \%$ (vol/vol) heat-inactivated fetal bovine serum (GIBCO Laboratories), and 10\% (vol/vol) fresh autologous serum]. Wright-stained smears showed that the cells were 95\% PMN. PMN were over 98\% viable as assessed by the $0.4 \%$ erythrosine dye exclusion test. Cells were suspended to $5 \times 10^{6}$ cells $/ \mathrm{ml}$ CTCM. For fungicidal assay, $100 \mu 1$ of cell suspensions were placed in flat-bottom microtest plate wells and $100 \mu 1$ CTCM were added to each well. MLHPO or methyl linoleate (ML; PV= $0.6 \mathrm{meq} / \mathrm{kg}$ ) dissolved in dimethyl sulfoxide (DMSO) was added to the PMN suspensions. The final concentrations of MLHPO, ML and DMSO in culture solutions were $245 \mu \mathrm{M}, 245 \mu \mathrm{M}$, and $128 \mathrm{~m} \mathrm{M}$, respectively. After $4 \mathrm{~h}$ of culturing, PMN were washed twice with CTCM and $200 \mu 1$ of $C$. albicans [5,000 colonyforming units (CFU)/ml CTCM] was added. Cultures were incubated for 15, 30, $60,120,180$ and $240 \mathrm{~min}$ at $37^{\circ} \mathrm{C}$ in $5 \% \mathrm{CO}_{2}-95 \%$ air. After incubation, well contents were removed and placed into $5 \mathrm{ml}$ of distilled water, and each well was washed five times with $0.2 \mathrm{ml}$ of distilled water. The culture contents and washings were diluted to $10 \mathrm{ml}$. After the diluted fluid was vigorously mixed, $1 \mathrm{ml}$ of harvested material was plated on 5\% sheep red blood cell trypticase soy agar plates, and CFU per culture were determined after 2 days at room temperature. The percent CFU was calculated by the formula: (experimental CFU divided by inoculum CFU) $\times 100$. For observation of phagocytosis, PMN $\left(5 \times 10^{5}\right)$ were cultured in $200 \mu \mathrm{l}$ CTCM on microtest plate wells. MLHPO or ML dissolved in DMSO were added to the PMN suspensions. The final concentrations of MLHPO, ML and DMSO in culture solutions were $245 \mu \mathrm{M}, 245 \mu \mathrm{M}$, and $128 \mathrm{~m} \mathrm{M}$, respectively. After $4 \mathrm{~h}$ of culturing (at $37^{\circ} \mathrm{C}$ in an atmosphere of humidified $5 \% \mathrm{CO}_{2} / 95 \%$ air), cultured PMN were washed twice with CTCM. Then PMN $\left(5 \times 10^{5}\right)$ and $C$. albicans $\left(15 \times 10^{5} \mathrm{CFU}\right)$ were incubated in $200 \mu 1$ of CTCM for $15,30,60,120$, 180 , and $240 \mathrm{~min}$ at $37^{\circ} \mathrm{C}$ in $5 \% \mathrm{CO}_{2}-95 \%$ air. Cells were pelleted by centrifugation $(300 \times g, 5 \mathrm{~min})$ and suspended in $50 \mu 1$ of CTCM, and the phagocytosis was observed under a light microscope. About 150 PMNs were observed in each suspension. Percent of phagocytosis was determined by the formula: (number of PMN with one ingested fungi or more divided by the number of PMN examined) $\times 100$. Viability of PMN after the treatment with DMSO, ML, or MLHPO was assessed by the $0.4 \%$ erythrosine dye exclusion test.

In cases of untreated, DMSO-treated, and ML-treated PMN, CFU of $C$. 
albicans were decreased to around 20, 10 and 5\% after 120,180 and $240 \mathrm{~min}$ of incubations with fungi, respectively (Fig. 1). By contrast, CFU was over $80 \%$ in the MLHPO-treated PMN throughout experimental duration. This result shows fungicidal activity of human PMN was depressed by the culturing with MLHPO before the incubation with fungi. By the $4 \mathrm{~h}$ of culturing with DMSO, ML or MLHPO, PMN were over 95\% viable, respectively. After $15 \mathrm{~min}$ of incubation with fungi, the phagocytosis was already 86,95 , and $86 \%$ in untreated, DMSOtreated, and ML-treated PMN, respectively (Fig. 2). In the case of MLHPOtreated PMN, the phagocytosis was depressed throughout experimental duration. Degree of the depression was dependent on the concentration of MLHPO. Figure 3 shows the influence of the culturing time with MLHPO on phagocytic activity of human PMN. The degree of depression in phagocytosis tended to be dependent on the culturing time with MLHPO also. From these results, it should be assumed that MLHPO-treated PMN could not kill the fungi because of the impairment of the phagocytosis by MLHPO.

This study shows that phagocytic activity of human PMN is depressed by lipid hydroperoxides.

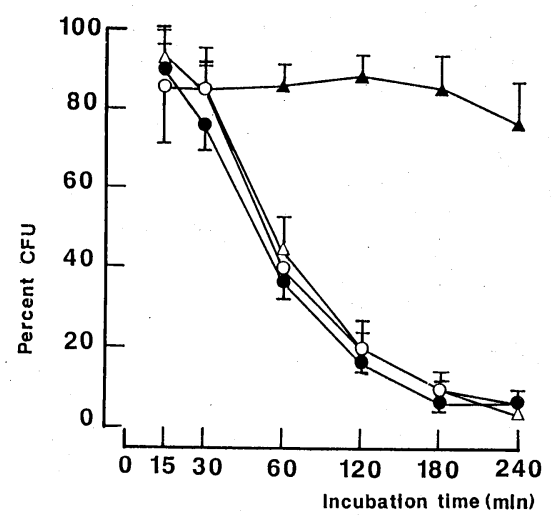

Fig. 1

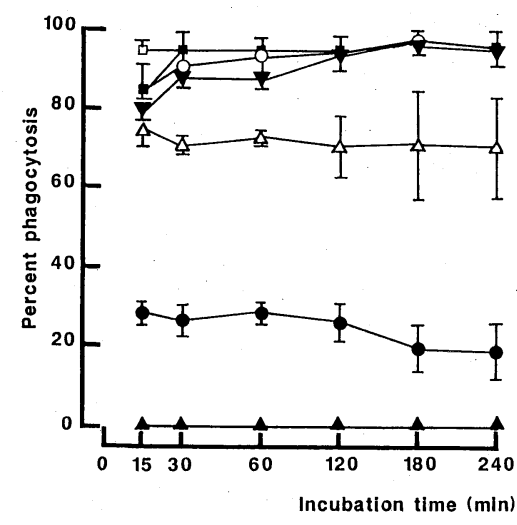

Fig. 2

Fig. 1. Effect of methyl linoleate hydroperoxides (MLHPO) on fungicidal activity of human PMN. PMN were cultured with MLHPO or ML dissolved in DMSO for $4 \mathrm{~h}$. Then cultured PMN were washed and incubated with $C$. albicans. Untreated, O; DMSO (128 mM)-treated, $\triangle$; ML (245 $\mu$ M)-treated, ๑; MLHPO $(245 \mu \mathrm{M})$-treated, $\Delta$. Values represent mean $\pm \mathrm{SD}$ of quadruplicate cultures.

Fig. 2. Effect of methyl linoleate hydroperoxides (MLHPO) on phagocytosis of human PMN. PMN were cultured with graded concentrations of MLHPO or ML dissolved in DMSO for $4 \mathrm{~h}$. Then cultured PMN were washed and incubated with $C$. albicans. Untreated PMN, O; DMSO (128 mM)-treated PMN, $\square$; ML (245 $\mu \mathrm{M}$ )-treated PMN, $\square$; MLHPO-treated PMN: $\nabla, 25 ; \triangle, 123 ; \bullet$, $184 ; \triangle, 245 \mu \mathrm{M}$. Values represent mean $\pm \mathrm{SD}$ of triplicate cultures. 


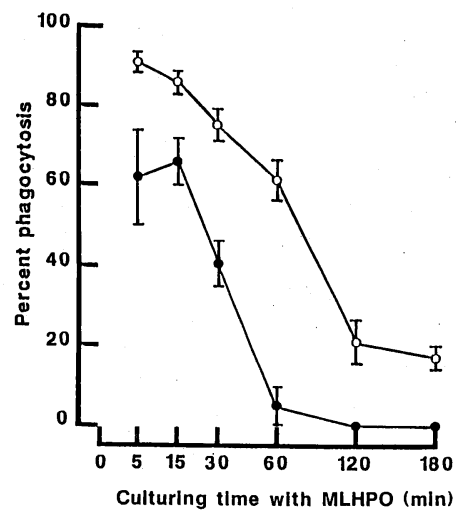

Fig. 3. Effect of culturing time with MLHPO on phagocytosis of human PMN. PMN were cultured with MLHPO dissolved in DMSO for graded times $(5,15$, $30,60,120$, and $180 \mathrm{~min}$ ). Then cultured PMN were washed and incubated with C. albicans for $2 \mathrm{~h}$. MLHPO: $\bigcirc, 184 ; \bullet, 245 \mu \mathrm{M}$. Values represent mean $\pm \mathrm{SD}$ of triplicate cultures.

\section{REFERENCES}

1) Kaneda, T., and Miyazawa, T. (1987): Lipid peroxides and nutrition. in World Review of Nutrition and Dietetics, 50, ed. by Bourne, G. H., Karger, Basel, pp. 186197.

2) Slater, T. R. (1984): Free-radical mechanisms in tissue injury. Biochem. J., 222, 1-15.

3) Miyazawa, T. (1989): Determination of phospholipid hydroperoxides in human blood plasma by a chemiluminescence-HPLC assay. Free Radical Biol. Med., 7, 209-217.

4) Oarada, M., Ito, E., Terao, K., Miyazawa, T., Fujimoto, K., and Kaneda, T. (1988): The effect of dietary lipid hydroperoxide on lymphoid tissues in mice. Biochim. Biophys. Acta, 960, 229-235.

5) Oarada, M., Majima, T., Miyazawa, T., Fujimoto, K., and Kaneda, T. (1989): The effect of dietary autoxidized oils on immunocompetent cells in mice. Biochim. Biophys. Acta, 1012, 156-160.

6) Baehner, R. L., Boxer, L. A., Allen, J. M., and Davis, J. (1977): Autooxidation as a basis for altered function by polymorphonuclear leukocytes. Blood, 50, 327-335.

7) Oarada, M., Miyazawa, T., and Kaneda, T. (1986): Distribution of ${ }^{14} \mathrm{C}$ after oral administration of $\left[\mathrm{U}-{ }^{14} \mathrm{C}\right]$-labeled methyl linoleate hydroperoxides and secondary oxidation products in rats. Lipids, 21, 150-154. 